\title{
Preparasi dan Karakterisasi Senyawa Tanin dari Daun Stevia (Stevia Rebaudiana) Menggunakan Instrumen HPLC sebagai Gula Pereduksi dalam Pembuatan Sukrosa
}

\author{
Cecep Setiawan*1, Nur Jannah Asrilya ${ }^{2}$ \\ Energi Bersih Indonesia (ENERBI) ${ }^{1}$, UNS ${ }^{2}$ \\ *E-mail: cecepsetia1@gmail.com
}

\begin{abstract}
Abstrak
Daun stevia merupakan salah satu jenis tanaman herbal yang menghasilkan sukrosa alami yang dapat dimanfaatkan dalam aplikasi pemanis dalam skala industri maupun rumah tangga. Metode penelitian yang digunakan dalam penelitian ini adalah ekstraksi senyawa tannin menggunakan karbon aktif. Karbon aktif dianalisis senayawa kimianya dan diidentifikasi gugus fungsi menggunakan FTIR. Senyawa tannin dari daun stevia dilakukan proses ektraksi dengan menggunakan perut etanol dan dianalisis senyawa kandungan tannin dengan menggunakan HPLC. Karbon aktif yang digunakan dalam proses ekstraksi sesuai dengan standar SNI dalam batas pemakaian penggunaanya sebagai adsorben dalam proses adsorpsi senyawa tannin. Gugus fungsiyang dihasilkan dari karbon aktif adalah vibrasi ulur $\mathrm{O}-\mathrm{H}, \mathrm{C}-\mathrm{O}, \mathrm{C}=\mathrm{O}, \mathrm{C}-\mathrm{H}$ aromatik dan $\mathrm{C}-\mathrm{H}$ finger print. Kadar senyawa kandungan tannin dari daun stevia yaitu 0,0122\% dan 0,0123\% dengan menggunakan pelarut etanol 30\% dan 70\%.
\end{abstract}

Kata kunci: daun stevia; karbon aktif; tanin

\begin{abstract}
Stevia leaf is a type of herbal plant that produces natural sucrose which can be used in industrial and household sweetener applications. The research method used in this research is the extraction of tannin compounds using activated carbon. Activated carbon was analyzed for chemical compounds and identified functional groups using FTIR. Tannin compounds from stevia leaves were extracted using ethanol stomach and analyzed for tannin compounds using HPLC. Activated carbon used in the extraction process is in accordance with SNI standards within the limits of its use as an adsorbent in the tannin compound adsorption process. The functional groups generated from activated carbon are stretching vibrations of $\mathrm{O}-\mathrm{H}, \mathrm{C}-\mathrm{O}, \mathrm{C}=\mathrm{O}, \mathrm{C}-\mathrm{H}$ aromatic and $\mathrm{C}-\mathrm{H}$ finger print. The compound levels of the tannin content of stevia leaves were $0.0122 \%$ and $0.0123 \%$ using $30 \%$ and $70 \%$ ethanol solvent.
\end{abstract}

Keywords: stevia leaves; activated carbon; tannins 


\section{Pendahuluan}

\begin{abstract}
Zaman milenial merupakan zaman dimana manusia membutuhkan segala sesuatu dengan praktis, salah satunya yaitu pemanis buatan (Tidore dkk, 2012). Pemanis digunakan untuk meningkatkan cita rasa dalam suatu makanan. Dalam bahan makanan pemanis dibedakan menjadi dua yaitu pemanis alamai da pemanis buatan. Salah satu pemanis yang banyak digunakan adalah gula (Wang, 2002). Gula diperoduksi dari gula tebu yang mengalami pemrosesan sehingga dihasilkan sukrosa. Sukrosa yang dihasilkan oleh tebu memiliki nilai kalori yang tinggi yang dapa menjadi pemicu penyakit berbahaya yaitu diabetes (Jaiswal dkk, 2018). Banyak para pelaku usaha baik industri kecil maupun menengah menggunakan pemanis buatan yang memiliki harga relatif murah dan rendah kalori. Dibalik muranya pemanis tersebut mengandung bahan kimia berbahaya apabila dikonsumsi dalam jumlah banyak dan secara terus
\end{abstract}

Stevia merupakan salah satu tanaman yang dapat menghasilkan sukrosa yang dibutuhkan tubuh(Ashok dkk, 2012). Sukrosa yang dihasilkan daun stevia memiliki nilai kalori yang rendah dan tidak menimbulkan efek samping bagi kesehatan tubuh (Schenk dkk, 2002). Bagi seseorang yang membutuhkan diet ketat untuk kesehatan atau untuk mengurangi kandungan gula tubuh maka sukrosa dari daun stevia merupakan salah satu alternatifnya. Gula pereduksi dari daun stevia memiliki sifat non kasinogeni sehingga sangat aman dan dapat dikonsumsi dalam jangka waktu panjang (Lutony, 1993).

Daun stevia mengandung senyawa metabolit sekunder yang dapat bermanfaat bagi tubuh (Hui, 2016). Setiap gram ekstrak dari daun stevia mengandung senyawa tannin, terpen dan stigmasterol (Wang, 2002). Disamping itu daun stevia memiliki kekurangan yaitu munculya rasa getir yang dihasilkan karena adanya kandungan senyawa tannin (Samuel dkk, 2018).
Senyawa tanin menghasilkan rasa pahit apabila langsung dikonsumsi (Hossain dkk, 2017). Beberapa hewan pemakan tumbuhan akan menghindari memakan tanaman yang mengandung senyawa tannin karena akan membentuk senyawa komplek lain. Senyawa tannin merupakan salah satu senyawa fenol dengan massa molekul besar (Goyal dkk, 2010).

Dalam proses produksi pembuatan gula menggunakan daun stevia sangat dihindari timbunya rasa pahititu. Kandungan tannin dalam ekstrak daun stevia tersebut harus dihilangkan salah satunya yaitu diekstraksi dengan menggunakan karbon aktif sehingga dapat dihasilkan gula yang mengandung sukrosa tanpa adanya kandungan tannin tersebut.

\section{Metode Penelitian}

Metode yang digunakan dalam penelitian ini adalah sebagai berikut.;

\section{Ekstraksi daun stevia}

Pada penelitian ini digunakan daun stevia yang diperoleh dari Tawangmangu, Jawa Tengah. Daun stevia dilakukan preparasi sampel terlebih dahulu dengan proses maserasi. Pada proses maserasi daun stevia ini digunakan pelarut etanol sehingga diperoleh ekstrak kasar dari daun stevia. Ekstrak kasar tersebut kemudian dilakukan ekstraksi lebih lanjut dengan menggunakan destilasi. Proses destilasi dilakukan pada suhu $70^{\circ} \mathrm{C}$.

\section{Aktivasi karbon aktif}

Karbon yang diperoleh dari hasil pengarangan dilakukan proses aktivasi. Tujuan aktivasi ini untuk mengaktifkan situs aktif dari karbon aktif. Proses aktivasi menggunakan $\mathrm{KOH}$ dilakukan pada suhu $230^{\circ} \mathrm{C}$ menggunakan furnace.

Pemisahan tanin dari ekstrak daun stevia

Pada proses pemisahan tanin ini digunakan karbon aktif. Karbon aktif terlebih dahulu dilakukan aktivasi dengan 
menggunakan $\mathrm{KOH}$. Kemudian karbon aktif tersebut dilewatkan kolom bersama dengan filtrat yang diperoleh. Karbon aktif melakukan proses adsorsi pada proses pengolomon sampel sehingga didapat filtrate murni.

Tahap pengeringan ekstrak daun stevia

Filtrat yang deiperoleh kemudian dilakukan freeze dry untuk tahap pengeringan. Hasil yang diperoleh ini nanti yang akan dilakukan analisis menggunakan instrument HPLC.

\section{Hasil Penelitian dan Pembahasan}

Penelitian ekstraksi daun stevia ini digunakan karbon aktif dalam proses ekstraksi awalnya. Karbon aktif yang diguakan harus memenuhi standar karbon aktif yang disyaratkan oleh SNI 1992. Tabel 1 merupakan hasil uji analisis karbon aktif yang digunakan dalam penelitian ini.

Berdasarkan tabel 1, karbon aktif yang dihasilkan sudah memenuhi standar
SNI tentang penggunaan karbon aktif. Karbon aktif inilah yang digunakan dalam ekstraksi senyawa tannin dari produksi gula pada daun stevia.

Tabel 1. Sifat fisika dan kimia dari karbon aktif

\begin{tabular}{lcc}
\hline \multicolumn{1}{c}{ Jenis } & Parameter & Hasil \\
Persyaratan & Maksimum 15\% & $2,45 \%$ \\
\hline $\begin{array}{l}\text { Hasil } \\
\text { penelitian }\end{array}$ & & \\
\hline $\begin{array}{l}\text { Kadar zat } \\
\text { menguap }\end{array}$ & Maksimum 25 \% & $13,86 \%$ \\
\hline $\begin{array}{l}\text { Kadar } \\
\text { karbon } \\
\text { terikat }\end{array}$ & Minimum 65 \% & $83,21 \%$ \\
\hline Kadar abu & Maksimum 10\% & $4,32 \%$ \\
\hline
\end{tabular}

Karbon aktif yang dihasilkan kemudian dianalisis lebih lanjut gugus fungsinya menggunakan FTIR. Berikut hasil spectra FTIR darikarbon aktif.

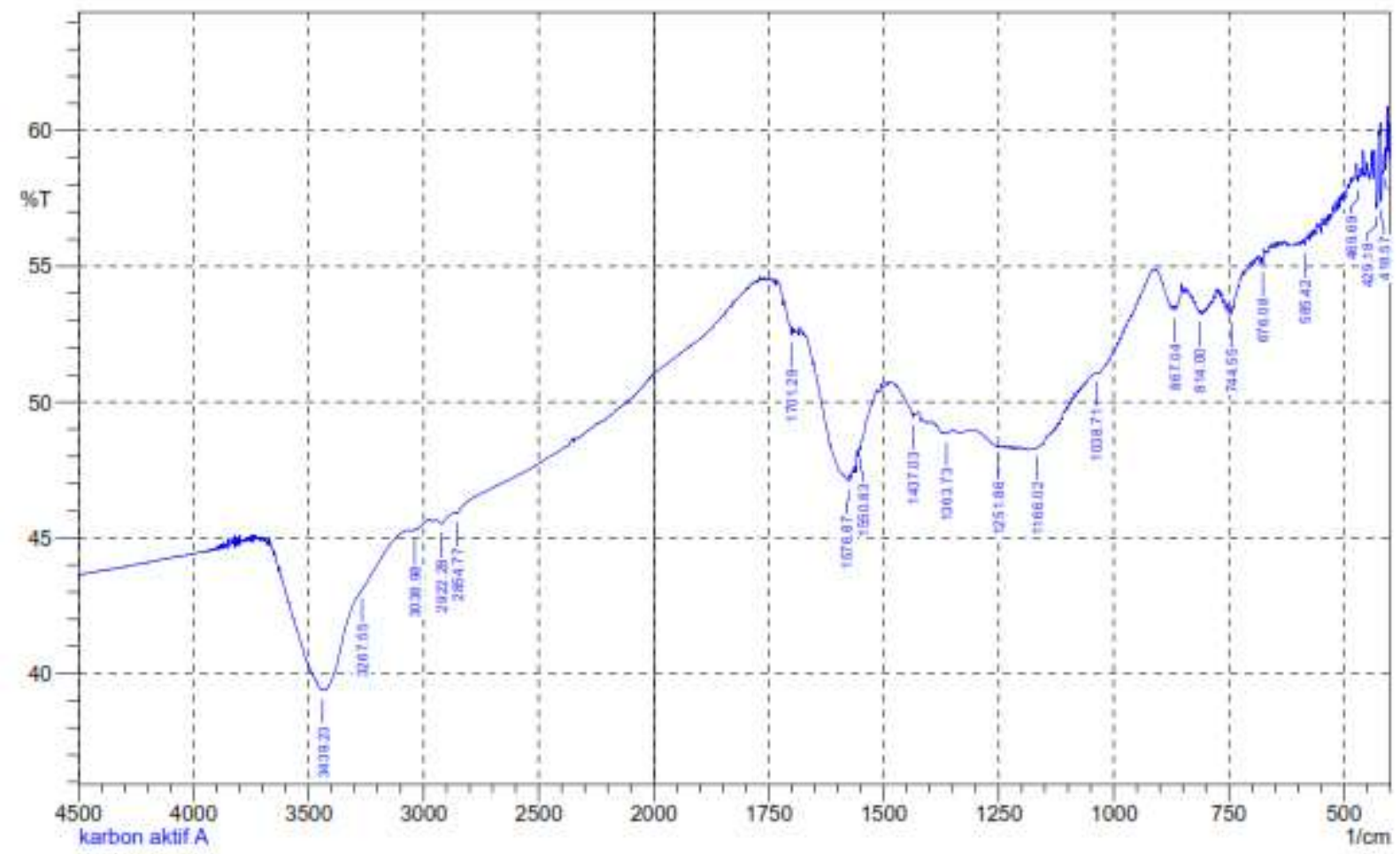

Gambar 1. FTIR karbon aktif 
Berdasarkan gambar 1 diatas dapat diketahui jenis gugus fungsi yang terdapat dalam karbon aktif yang digunakan dalam proses ekstraksi senyawa tanin.

Pada Tabel 2 dapat diketahui jenis gugus fungsi yang terkandung dalam karbon aktif. Pada karbon aktif terlihat gugus fungsi dari vibrasi ulur $\mathrm{O}-\mathrm{H}, \mathrm{C}-\mathrm{O}, \mathrm{C}=\mathrm{O}, \mathrm{C}-\mathrm{H}$ aromatik dan $\mathrm{C}-\mathrm{H}$ finger print. Gugus $-\mathrm{OH}$ yang dihasilkan dari karbon aktif mempunyai peak yang lebih lebar dibandingkan alumina dimana pada karbon aktif vibrasi $-\mathrm{OH}$ terdeteksi pada bilangan gelombang 3441,16. Gugus fungsi yang dihasilkan dari karbon aktif ini sesuai dengan karbon aktif dari penelitian yang dilakukan oleh Budiono dkk, 2012. Karbon aktif yang dihasilkan dari limbah tempurung kelapa Budiono menginformasikan adanya pita serapan pada bilangan gelombang 3433,29-3425,58 cm-1 muncul vibrasi ulur pada gugus $\mathrm{O}-\mathrm{H}$. Vibrasi ini didukung pita serapan pada bilangan gelombang 1165,0-1111,0 cm-1 yang merupakan vibrasi C-O dan pada bilangan gelombang $\quad 1620,35-1581,63 \quad \mathrm{~cm}-1$ merupakan vibrasi $\mathrm{C}=\mathrm{C}$.

Tabel 2. Gugus fungsi karbon aktif

\begin{tabular}{lcc}
\hline \multicolumn{1}{c}{ Gugus } & $\begin{array}{c}\text { Range Bilangan } \\
\text { Fungsi }\end{array}$ & $\begin{array}{c}\text { Karbon } \\
\text { aktif }\end{array}$ \\
\hline $\begin{array}{l}\text { Variasi ulur } \\
\text { pada gugus } \\
\text { O-H }\end{array}$ & $2500-3000$ & 3441,16 \\
\hline $\mathrm{C}-\mathrm{O}$ & $1260-1000$ & 1166,98 \\
\hline $\mathrm{C}=\mathrm{O}$ & $1760-1670$ & 1687,79 \\
\hline $\begin{array}{l}\mathrm{C}=\mathrm{C} \\
\text { aromatic }\end{array}$ & $1600-1500$ & 1554,69 \\
\hline $\begin{array}{l}\mathrm{C}=\mathrm{H} \text { finger } \\
\text { print }\end{array}$ & $2000-1600$ & 1617,38 \\
\hline
\end{tabular}

Kandungan senyawa ekstrak stevia sebagian besar merupakan senyawa non volatil. HPLC adalah suatu metode deteksi dan kuantifikasi yang sensitifitasnya sangat tinggi untuk berbagai senyawa kimia dalam suatu sampel partikular menggunakan absorbansi UV-Vis. HLPC dengan fase normal kurang umum dibanding dengan fase terbalik. Yang dimaksud fase terbalik adalah fase diamnya lebih non polar dibanding fase geraknya. berhasil mengisolasi dan mengidentifikasi Rubiacordone A, suatu jenis glikosida antrakuinon baru dari akar Rubia cordifolia menggunakan HPLC fase terbalik dengan sistem elusi isokratik pada panjang gelombang $280 \mathrm{~nm}$. Condensed tanin dari $\mathrm{L}$. glaber menggunakan HPLC pada panjang gelombang yang sama.

Sebanyak $20 \mu \mathrm{L}$ sampel cair ekstrak stevia diinjeksikan ke dalam HPLC untuk dianalisis. Fase diam yang digunakan adalah C18. Fase gerak yang sering digunakan untuk pemisahan dengan fase terbalik adalah campuran larutan buffer-metanol atau campuran air-asetonitril. Dalam penelitian ini digunakan sistem pelarut asetonitril dan aquabides (80:20) (v/v). Sampel dielusi pada panjang gelombang $280 \mathrm{~nm}$. Tanin dapat dideteksi pada panjang gelombang tersebut. Senyawa fenolik dapat dideteksi pada range panjang gelombang $270-290 \mathrm{~nm}$ sehingga senyawa fenolik bebas juga dapat terdeteksi pada panjang gelombang $280 \mathrm{~nm}$. Semua golongan metabolit sekunder kecuali antosianin dapat terdeteksi pada panjang gelombang $280 \mathrm{~nm}$. Oleh karena itulah, ekstrak etanol dielusikan pada panjang gelombang $280 \mathrm{~nm}$, Pada panjang gelombang tersebut, senyawa tanin dalam ekstrak stevia dapat terdeteksi. Penentuan kadar tannin diukur dengan menggunakan asam tanat kurva standar (\%). Kurva standar asam tanat dapat dilihat pada Gambar 2.

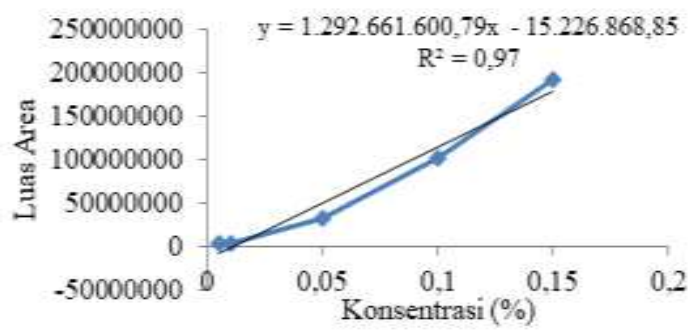

Gambar 2. Kurva Standar Asam Tanat untuk HPLC 
Hasil pengukuran kadar tanin pada ekstrak stevia dengan HPLC dapat dilihat pada kromatogram HPLC ekstrak stevia pada Gambar 1 menunjukkan kromatogram aquades $100 \mathrm{oC}$, etanol $30 \% 70 \mathrm{oC}$ dan etanol $70 \% 70$ oC yang memiliki jumlah serbuk hasil evaporasi yang paling banyak, terlihat bahwa kromatogram aquades $100 \mathrm{oC}$ hanya memiliki 1 puncak pada waktu retensi 1,3 dan pada kromatogram etanol 30\% 70oC dan etanol $70 \%$ 70oC memliki beberapa puncak yang menandakan ekstrak tersebut belum murni, terlihat waktu retensi pada 1,3 menandakan tanin.
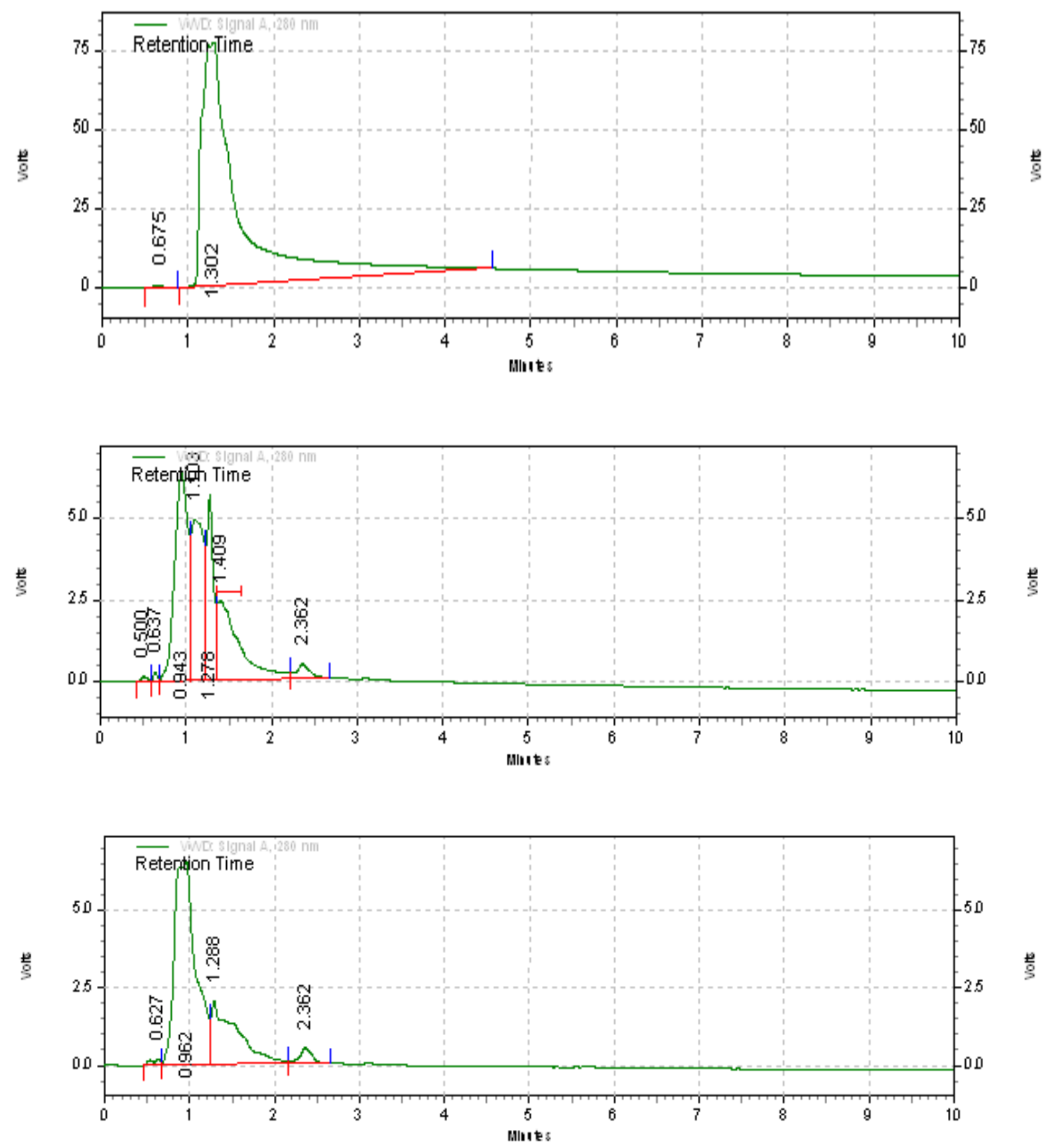

Gambar 3. Kromatogram hasil uji HPLC ekstrak tanin 
Pelarut etanol dapat memberikan serapan karena pelarut yang digunakan bukan pelarut murni, dalam hal ini etanol $30 \%$ dan $70 \%$. Sehingga, serapan tersebut diduga merupakan serapan dari senyawa pengotor atau komponen senyawa yang terkandung dalam etanol. Diperoleh kadar tanin dari masing masing kromatogram yaitu 0,0424\%, 0,0122\% dan 0,0123\% dan menandakan kadar tanin paling tinggi yaitu ekstrak aquades $100^{\circ} \mathrm{C}$.

\section{Simpulan}

Karbon aktif yang digunakan dalam mengekstraksi senyawa tannin dalam daun stevia telag memenuhi standar SNI. Senaywa tannin dari daun stevia berhasil diekstraksi melalui pengujian menggunakan unstrumen HPLC. Kadar senyawa kandungan tannin dari daun stevia yaitu 0,0122\% dan 0,0123\% dengan menggunakan pelarut etanol $30 \%$ dan $70 \%$.

\section{Ucapan Terima Kasih}

Jika perlu berterima kasih kepada pihak tertentu, misalnya sponsor penelitian, nyatakan dengan jelas dan singkat, hindari pernyataan terima kasih yang berbungabunga.

\section{Daftar Pustaka}

Ashok, P.K, Upadhyaya, K. 2012. Tannins are Astringent. Journal of Pharmacognosy and Phytochemistry. Vol. 1. No.3.

Hui, Y. H. 2016. Encyclopedia of Food Sciece and Technology Handbook. VCH Publisher, Inc. New York.
Goyal, K.S., Samsher. 2010. Stevia (Stevia rebaudiana) A Bio-Sweetener: Review. International Journal of Food Science and Nutrition. Vol. 61. No. 1.

Hossain, M.F., Islam, M.T., Islam, M.A., Akhtar, S. 2017. Cultivation and Uses of Stevia (Stevia rebaudiana Bertoni): A Review. African Journal of Food, Agriculture, Nutrition and Development. Vol. 7. No.4.

Jaiswal, H., Singh, O.J., Chauhan, A.,Sahu, M.K., Prakash, S.2018. Review on Tannins. Vol. 6. No.3.

Lutony, T. L. 1993. Tanaman Sumber Pemanis. Penebar Swadaya. Jakarta

Masters, K. 1979. Spray Drying Handbook. John Wiley and Sons. New York

Rangan, S. 1977. Manual of Analysis of Fruit and Vegetable Product. Tata Mc.graw-Hill Publishing, Ltd. New Delhi. Page 69

Samuel, P., Ayoob, T., Magnuson, B.A., Ursula, W., Jeppesen, P.B., Roger, P.J., Rowland, I., Mathews, R. 2018. Stevia Leaf to Stevia Sweetener: Exploring Its Science, Benefits, and Future Potential. Journal of Nutrition. Vol. 148. No.7.

Schenk, S. W. dan Hebbeda, R. E. 2002. Starch Hydrolysis Product, Worldwide Technology Production and Application. VCH Publisher Inc. New York

SNI. 1992. Cara Uji Makanan dan Minuman SNI 01-2891-1992. Badan standar nasional. Halaman 34-35. 